\title{
Emphysematous cystitis: diagnosed only if suspected
}

\author{
Shanmugasundaram Rajaian, ${ }^{\circledR}$ Pragatheeswarane Murugavaithianathan, \\ Karrthik Krishnamurthy, Lakshman Murugasen
}

Department of Urology, MIOT International, Chennai, Tamil Nadu, India

\section{Correspondence to}

Dr Shanmugasundaram Rajaian, ssrl25@gmail.com

SR and PM contributed equally.

Accepted 19 June 2019

\section{DESCRIPTION}

Emphysematous cystitis (EC) is rare and has a varied clinical spectrum ranging from incidental diagnosis to fulminant sepsis. ${ }^{1}$ Prompt diagnosis, bladder drainage and broad-spectrum antibiotics form the crux of management to prevent urosepsis and mortality. ${ }^{2}$ A 68 -year-old man with diabetes and hypertension presented to the emergency department with a history of vomiting, giddiness, fever and urinary frequency of 1 day duration. He gave a history of undergoing urethroplasty 10 years previously. He had a pulse rate of 92/ min, blood pressure of $100 / 70 \mathrm{~mm} \mathrm{Hg}$, tachypnoea $(24 / \mathrm{min})$ and fever $\left(39^{\circ} \mathrm{C}\right)$. He had leucocytosis (WBC-2.8 $\times 10^{9} / \mathrm{L}$ ), high random blood sugar $(480 \mathrm{mg} / \mathrm{dL})$, albuminuria and glycosuria. He was started on an intravenous injection of 500 $\mathrm{mg}$ imipenem three times a day and sliding scale insulin. He underwent X-ray pelvis (figure 1) and CT abdomen (figure 2) on day 1 . He required ionotropic support for management of sepsis. Urologist opinion was sought only after the final report of EC. On examination he had suprapubic fullness. Perurethral catheterisation had resistance to 14 Fr Foley catheter at the level of previous anastomotic site hence suprapubic catheterisation (SPC) was done. Around $500 \mathrm{~mL}$ purulent urine along with gas was drained after SPC placement. Escherichia coli was grown in the urine culture. His clinical condition improved with intravenous antibiotics and bladder drainage. He was tapered off from ionotropic support and discharged on SPC. He was planned for definitive management of urethral stricture on a later date.

EC is diagnosed by imaging but is usually underdiagnosed and under-reported. ${ }^{1}$ Nearly half of the cases in the literature were reported only in the last decade. ${ }^{1}$ E. coli is the most common culprit but various bacterial and fungal organisms were implicated in pathogenesis. ${ }^{1}$ Patients

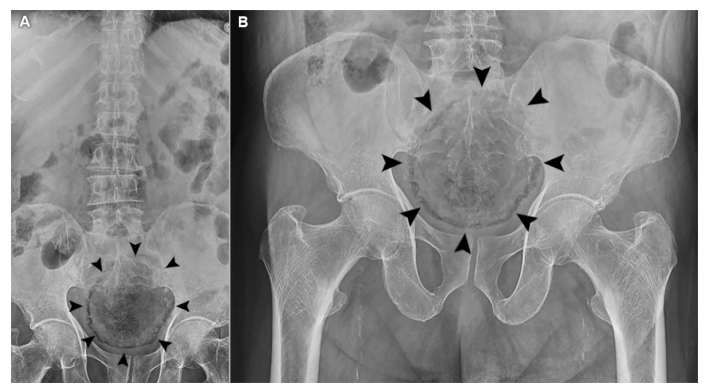

Figure $1 \quad(A, B)$ Plain X-ray of pelvis revealing circumferential radiolucency in the outline of bladder (black arrow heads).

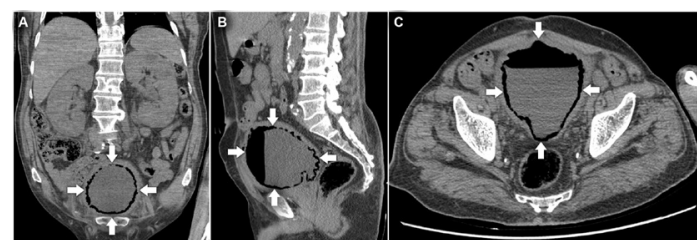

Figure $2 \quad(A, B, C)$ Coronal, sagittal and axial views of plain $\mathrm{CT}$ scan of abdomen demonstrating air in the lumen and also within the bladder wall (solid white arrows).

\section{Learning points}

CT scan is the gold standard in diagnosing a case of emphysematous cystitis but X-ray findings should not be overlooked.

- Prompt diagnosis with early bladder drainage and broad-spectrum antibiotics is mandatory to avoid morbidity and mortality.

with diabetic cystopathy, neurogenic bladder and urinary stasis secondary to urethral stricture or bladder outlet obstruction are more susceptible. Impaired host response and fermentation process leading to production of gas within the bladder is the most common factor in pathogenesis. ${ }^{1}$ On clinical suspicion around $80 \%$ of cases can be diagnosed based on plain radiography. ${ }^{1}$ Ultrasound findings may reveal abnormally thickened bladder wall and have low sensitivity, hence may be used for follow-up of recovering patients. ${ }^{3}$ CT scan is the gold standard in the diagnosis of this condition emphasising the low threshold for ordering the investigation for early successful management. ${ }^{3}$ Schicho et al reviewed the largest series on EC and concluded that despite the low mortality rate of EC a high degree of suspicion must be maintained to facilitate successful and conservative management. ${ }^{4}$ Delayed intervention can lead to emphysematous pyelonephritis, septic shock, bladder rupture and death. ${ }^{15}$ Patients not responding to medical management and those with necrotising infections might require surgical debridement. ${ }^{1}$ Immediate bladder drainage along with broad-spectrum antibiotics should be initiated in high-risk patients without delay to avoid morbidity and mortality. We report this case to emphasise the importance of radiological findings and awareness among emergency physicians for prompt diagnosis and referral.

Acknowledgements The authors thank Balasubramanian Rajendran for image editing. 
Contributors SR and LM examined and investigated the patient. They helped in planning, conducting and reporting of the study. MP conceived and designed the study. KK helped in acquisition and interpretation of the data. SR and MP are responsible for overall content of the manuscript.

Funding The authors have not declared a specific grant for this research from any funding agency in the public, commercial or not-for-profit sectors.

Competing interests None declared.

Patient consent for publication Obtained.

Provenance and peer review Not commissioned; externally peer reviewed.

\section{REFERENCES}

1 Thomas AA, Lane BR, Thomas AZ, et al. Emphysematous cystitis: a review of 135 cases. BJU Int 2007;100:17-20.

2 Wu YF, Kao CC, Tsuei YW, et al. Acute urinary retention as a manifestation of emphysematous cystitis. Am J Emerg Med 2015;33:604.

3 Eken A, Alma E. Emphysematous cystitis: The role of CT imaging and appropriate treatment. Can Urol Assoc J 2013;7:754-6.

4 Schicho A, Stroszczynski C, Wiggermann P. Emphysematous cystitis: mortality, risk factors, and pathogens of a rare disease. Clin Pract 2017;7:930.

5 Roels P, Decaestecker K, De Visschere P. Spontaneous Bladder Wall Rupture Due to Emphysematous Cystitis. J Belg Soc Radiol 2016;100:83.

Copyright 2019 BMJ Publishing Group. All rights reserved. For permission to reuse any of this content visit

https://www.bmj.com/company/products-services/rights-and-licensing/permissions/

BMJ Case Report Fellows may re-use this article for personal use and teaching without any further permission.

Become a Fellow of BMJ Case Reports today and you can:

- Submit as many cases as you like

- Enjoy fast sympathetic peer review and rapid publication of accepted articles

- Access all the published articles

Re-use any of the published material for personal use and teaching without further permission

\section{Customer Service}

If you have any further queries about your subscription, please contact our customer services team on +44 (0) 2071111105 or via email at support@bmj.com.

Visit casereports.bmj.com for more articles like this and to become a Fellow 